\title{
New ACE Inhibitor Designed from Nicotianamine and Its Docking Pose Prediction Using the Gold Program
}

\author{
Noboru Takada*, Takaharu Okada, Eri Kogawa, Yohsuke Sanada, Ayumi Ishidoya \\ Faculty of Agriculture and Life Science, Hirosaki University, Hirosaki, Japan \\ Email address: \\ takada@hirosaki-u.ac.jp (N. Takada) \\ ${ }^{*}$ Corresponding author \\ To cite this article: \\ Noboru Takada, Takaharu Okada, Eri Kogawa, Yohsuke Sanada, Ayumi Ishidoya. New ACE Inhibitor Designed from Nicotianamine and Its \\ Docking Pose Prediction Using the Gold Program. Journal of Drug Design and Medicinal Chemistry. Vol. 5, No. 3, 2019 , pp. 33-39. \\ doi: $10.11648 /$ j.jddmc.20190503.11
}

Received: July 16, 2019; Accepted: August 7, 2019; Published: August 23, 2019

\begin{abstract}
Hypertension is currently one of the most serious health issues worldwide. Nicotianamine, a non-peptide-type amino acid trimer, is ubiquitously present in higher plants and plays a role as an internal metal transporter. It is known that nicotianamine inhibits ACE activity and that oral treatment with the compound improves hypertension. However the mode of action remains unclear, due to lack of crystallographic data. Although a structure-activity relationship study of nicotianamine has the potential to uncover the details of the inhibition profile, the azetidine-2-carboxylic acid moiety in nicotianamine has become a critical barrier for further biochemical research due to limited commercial supply and difficulties with structural modification. In this paper, ten nicotianamine analogs without azetidine-2-carboxylic acid moiety were prepared and their inhibition of angiotensin I-converting enzyme was investigated. Among these analogs, a phenylalanine analog, $\left(2 S, 3^{\prime} S, 3^{\prime \prime} S\right)-N$ $\left\{3^{\prime}\right.$-(3"-amino-3"-carboxypropylamino)-3'-carboxypropyl $\}$ phenylalanine, displayed the most potent activity. The inhibition activity of the compound corresponded to that of captopril. These results suggested a possibility of structural modification of nicotianamie to develop antihypertensive drugs. Molecular docking studies with Gold were also performed to predict the binding poses of nicotianamine and its analog, suggesting that nicotianamine and its analogs combine a plausible allosteric site in an area away from the catalytic site in ACE.
\end{abstract}

Keywords: Nicotianamine, Structure-Activity-Relationship Study, Angiotensin I-Converting Enzyme Inhibitors, Molecular Docking Study, Allosteric Binding Site

\section{Introduction}

Hypertension is currently one of the most serious health issues worldwide. Renin-angiotensin system (RAS) is involved in the long-term regulation of blood pressure and volume in the human body and is considered to be one of the key targets for hypertension drugs. Angiotensin I-converting enzyme (ACE) is a RAS component that catalyzes hydrolysis of angiotensin I to generate the vasopressor angiotensin II. Hence, many ACE inhibitors (ACEIs) such as captopril [1-3] have been developed and are being used in hypertension therapy (Figure 1). The inhibition pattern of captopril is verified to be competitive, and the binding features of captopril with ACE have been well-established by X-ray crystallographic studies [4], thereby leading to the development of other antihypertensive drugs [5], such as enalapril, that bind to ACE in a similar manner.

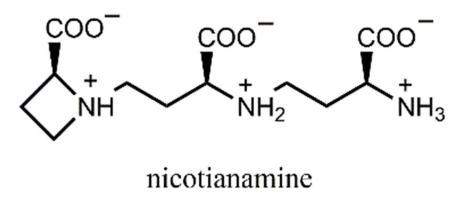<smiles>C[C@@H](CS)C(=O)N1CCC[C@H]1C(=O)O</smiles>

Figure 1. Structures of nicotianamine and captopril.

Nicotianamine, a non-peptide-type amino acid trimer, is ubiquitously present in higher plants and plays a role as an internal metal transporter [6-9]. Nicotianamine also inhibits ACE activity, and oral treatment with the compound improves hypertension in both spontaneously hypertensive rats (SHR) and Tsukuba hypertensive mice (THM) [10-12]. 
The synthase genes have already been observed in various plants [13-14], and overexpression of nicotianamine in transgenic plants has also been established [15]. The inhibition pattern was reported to be mixed noncompetitive [16]. Nicotianamine exhibited weak chelating effects for zinc, copper, and cobalt ions, although the role of nicotianamine is as an internal metal transporter in plants. These data suggest that nicotianamine is an allosteric ACEI, providing an alternate strategy in the development of ACEtargeted therapy. However, the nature of the allosteric site in ACE remains unclear to date, due to lack of crystallographic data. In this case, a structure-activity relationship (SAR) study of nicotianamine has the potential to uncover the details of the inhibition profile, which would lead to novel hypertensive drug development. However, the azetidine-2carboxylic acid moiety in nicotianamine has become a critical barrier for further biochemical research due to limited commercial supply (L-azetidine 2-carboxylic acid: ca 640 $\mathrm{USD} / \mathrm{g}$, L-phenylalanine: $c a 40 \mathrm{USD} / \mathrm{kg}$ ) and difficulties with structural modification. Our SAR study of nicotianamine showed that the azetidine-2-carboxylic acid moiety was not essential for the ACEI activity, leading to the development of a more potent ACE inhibitor, $\left(2 S, 3^{\prime} S, 3^{\prime \prime} S\right)-N-\left\{3^{\prime}\right.$-( $3^{\prime \prime}$-amino3 "-carboxypropylamino)-3'-carboxypropyl $\}$ phenylalanine

(6c). Furthermore, the docking features of nicotianamine were predicted using molecular modeling studies. This research is described in detail in this paper.

\section{Materials and Methods}

\subsection{General}

The ${ }^{1} \mathrm{H}$ NMR spectra $(500 \mathrm{MHz})$ were recorded in $\mathrm{D}_{2} \mathrm{O}$ or $\mathrm{CD}_{3} \mathrm{OD}$ on a Jeol JNM-ECA500 spectrometer with $H \mathrm{OD}\left(\delta_{\mathrm{H}}\right.$ $4.63 \mathrm{ppm})$ or $\mathrm{CH} \mathrm{D}_{2} \mathrm{OD}\left(\delta_{\mathrm{H}} 3.30 \mathrm{ppm}\right)$ as an internal standard. The HRESIMS spectra were recorded on a Hitachi NanoFrontier LD spectrometer. Hippuryl-L-histidyl-Lleucine (HHL) was purchased from the Peptide Institute (Osaka, Japan). Captopril and cyanuric chloride were obtained from Wako Pure Chemical Industries, Ltd. ACE from rat brains were prepared as described previously [17]. Solvents and reagents were purchased from commercial sources and used without further purification. Molecular mechanics calculation and docking calculations were performed using Spartan'08 software (Wavefunction, Inc.) and Gold 5.2 software (The Cambridge Crystallographic Data Centre).

\subsection{Chemistry}

\subsubsection{Isolation of Nicotianamine from Pumpkin}

Pumpkin $(2.0 \mathrm{~kg})$ purchased at a local food store was crushed with a blender and filtered through a cotton cloth. The obtained filtrate was centrifuged at $12000 \times \mathrm{g}$ for $30 \mathrm{~min}$ to obtain the pumpkin extract as a supernatant. The subsequent isolation process was conducted under guidance with an ACEI assay as described in Section 3. The extract was chromatographed (column: AG 1-X8, $\phi 65 \times 300 \mathrm{~mm}$; eluent: $\mathrm{H}_{2} \mathrm{O}, 2 \mathrm{~L} \rightarrow 0.1 \mathrm{M}$ aqueous $\mathrm{HCl}, 1 \mathrm{~L} \rightarrow 0.3 \mathrm{M}, 1 \mathrm{~L} \rightarrow$ $0.5 \mathrm{M}, 2 \mathrm{~L})$ to yield fr-1 4. Next, fr-3 (2.03 g) was chromatographed (column: Dowex 50-X2, ф 65×290 mm; eluent: $\mathrm{H}_{2} \mathrm{O} \rightarrow 0.1 \mathrm{M}$ aqueous $\mathrm{HCl} \rightarrow 0.3 \mathrm{M} \rightarrow 0.5 \mathrm{M} \rightarrow 2$ $\mathrm{M} \rightarrow 4 \mathrm{M}, 1 \mathrm{~L}$ each) to yield fr-3-1 6. Fr-3-6 (945 mg) was gel-filtrated (column: Sephadex G-25 gel, $\phi 26 \times 535 \mathrm{~mm}$; eluent: $\mathrm{H}_{2} \mathrm{O}$; flow rate: $1.5 \mathrm{~mL} / \mathrm{min}$ ) to yield fr-3-6-1 3. Fr-36-2 (195 mg, elution volume: $210-240 \mathrm{~mL}$ ) was separated (column: Sep-Pak ${ }^{\circledR}$ Vac 35 cc $(10$ g) C18 cartridge; eluent: $\mathrm{H}_{2} \mathrm{O} \rightarrow 20 \%$ aqueous $\mathrm{MeOH} \rightarrow 40 \% \rightarrow 60 \% \rightarrow 80 \% \rightarrow$ $\mathrm{MeOH}, 36 \mathrm{~mL}$ each, containing $0.1 \% \mathrm{AcOH}$ ) to afford active fr-3-6-2-1 (165 mg). Finally, the fr-3-6-2-1 (32 mg) was purified using HPLC (column: TSK-SAX, $\phi 6.0 \times 150 \mathrm{~mm}$; eluent: aqueous $\mathrm{NH}_{3}(\mathrm{pH}$ 9.5):0.1 M aqueous $\mathrm{HCOOH}=$ $100: 1 \rightarrow$ 95:5, linear gradient; flow rate: $1.0 \mathrm{~mL} / \mathrm{min}$, detection at $230 \mathrm{~nm})$ to yield nicotianamine $(4.5 \mathrm{mg}$, retention time: $45-55 \mathrm{~min}) ; \delta_{\mathrm{H}}\left(\mathrm{D}_{2} \mathrm{O}, 25^{\circ} \mathrm{C}\right) 1.91(1 \mathrm{H}, \mathrm{m})$, $1.98(1 \mathrm{H}, \mathrm{m}), 2.01(1 \mathrm{H}, \mathrm{m}), 2.08(1 \mathrm{H}, \mathrm{dq}, J=14.9,7.4 \mathrm{~Hz})$, $2.36(1 \mathrm{H}, \mathrm{dq}, J=12.3,9.6 \mathrm{~Hz}), 2.56(1 \mathrm{H}, \mathrm{ddt}, J=4.4,12.3$, $9.6 \mathrm{~Hz}), 2.97(1 \mathrm{H}, \mathrm{m}), 3.00(1 \mathrm{H}, \mathrm{m}), 3.17(1 \mathrm{H}, \mathrm{ddd}, J=6.1$, 9.1, $13.0 \mathrm{~Hz}), 3.24(1 \mathrm{H}, \mathrm{ddd}, J=5.9,9.2,13.0 \mathrm{~Hz}), 3.52(1 \mathrm{H}$, $\mathrm{m}), 3.71(1 \mathrm{H}, \mathrm{dd}, J=5.7,7.4 \mathrm{~Hz}), 3.78(1 \mathrm{H}, \mathrm{q}, J=9.6 \mathrm{~Hz})$, $3.92(1 \mathrm{H}, \mathrm{dt}, J=4.4,9.6 \mathrm{~Hz}), 4.58(1 \mathrm{H}, \mathrm{t}, J=9.6 \mathrm{~Hz})$; HRESIMS: $\mathrm{MH}^{+}$, found 304.1510. $\mathrm{C}_{12} \mathrm{H}_{22} \mathrm{~N}_{3} \mathrm{O}_{6}$ requires 304.1509 .

\subsection{2. (3'S)-N-(3'-Benzyloxycarbonyl-3'-Tert- Buthoxycarbonylaminopropyl)Glycine Benzyl Ester (3a)}

To a stirring solution of aldehyde 1 (150 mg, $0.49 \mathrm{mmol})$ and toluenesufonium salt of glycine benzyl ester (2a, $247 \mathrm{mg}$, $0.73 \mathrm{mmol})$ dissolved in $\mathrm{MeOH}(2.5 \mathrm{~mL})$ was added sodium cyanoborohydride (46 mg, $0.73 \mathrm{mmol}$ ). The mixture was stirred at room temperature overnight and then was poured into a mixture of saturated aqueous $\mathrm{NaHCO}_{3}(50 \mathrm{~mL})$ and EtOAc $(50 \mathrm{~mL})$. After the removal of $\mathrm{MeOH}$ in vacuo, the aqueous mixture was extracted with EtOAc $(50 \mathrm{~mL} \times 3)$. The combined organic layer was washed with brine $(50 \mathrm{~mL})$, dried over $\mathrm{Na}_{2} \mathrm{SO}_{4}$, and then concentrated in vacuo. Silica gel column chromatography of the residue (hexane: EtOAc $=3: 1$ $\rightarrow 2: 1 \rightarrow 1: 1)$ yielded $3 \mathrm{a}(150 \mathrm{mg}, 67 \%) ; \delta_{\mathrm{H}}\left(\mathrm{CD}_{3} \mathrm{OD}\right) 1.44$ $(9 \mathrm{H}, \mathrm{s}), 1.95(1 \mathrm{H}, \mathrm{m}), 2.41(1 \mathrm{H}, \mathrm{dddd}, J=1.6,7.0,9.1,12.4$ $\mathrm{Hz}), 3.40(1 \mathrm{H}, \mathrm{dt}, J=1.6,9.5 \mathrm{~Hz}), 3.46(1 \mathrm{H}, \mathrm{ddd}, J=7.0$, 9.5, 9.7 Hz), $4.05(1 \mathrm{H}, \mathrm{d}, J=17.7 \mathrm{~Hz}), 4.23(1 \mathrm{H}, \mathrm{d}, J=17.7$ $\mathrm{Hz}), 4.26(1 \mathrm{H}, \mathrm{dd}, J=9.1,9.5 \mathrm{~Hz}), 5.17(4 \mathrm{H}, \mathrm{s}), 7.29-7.37$ $(10 \mathrm{H}, \mathrm{m})$; HRESIMS: $\mathrm{MH}^{+}$, found 457.2330. $\mathrm{C}_{25} \mathrm{H}_{33} \mathrm{~N}_{2} \mathrm{O}_{6}$ requires 457.2339.

\subsection{3. (3'S)-N-(3'-Amino-3'-Carboxy-Propyl) Glycine (4a)}

Amine $3 \mathrm{a}(28.3 \mathrm{mg}, 0.062 \mathrm{mmol})$ was dissolved in trifluoroacetic acid $(1 \mathrm{~mL})$, and the mixture was left to stand at room temperature for $1 \mathrm{~h}$ and then was concentrated in vacuo. To a stirred solution of the residue in a mixture of EtOH $(2 \mathrm{~mL})$ and $\mathrm{H}_{2} \mathrm{O}(0.5 \mathrm{~mL})$ was added a catalytic amount of $10 \% \mathrm{Pd}-\mathrm{C}$ at room temperature. The mixture was stirred vigorously under a $\mathrm{H}_{2}$ atmosphere at room temperature for $20 \mathrm{~min}$ and then filtered through a pad of celite. The filtrate was concentrated in vacuo to yield 5a (11 
mg) quantitatively; $\delta_{\mathrm{H}}\left(\mathrm{D}_{2} \mathrm{O}\right) 2.06(1 \mathrm{H}, \mathrm{m}), 2.53(1 \mathrm{H}, \mathrm{m})$, 3.42-3.52 (2H, m), $3.97(1 \mathrm{H}, \mathrm{dd}, J=5.5,7.4 \mathrm{~Hz}), 4.07-4.16$ $(2 \mathrm{H}, \mathrm{m})$; HRESIMS: $\mathrm{MH}^{+}$, found 177.0883. $\mathrm{C}_{6} \mathrm{H}_{13} \mathrm{~N}_{2} \mathrm{O}_{4}$ requires 177.0875 .

Other compounds (4b-3e, 6a-6e) were prepared in a similar way (2.2.2. and 2.2.3.) with corresponding amino acids counter parts $(2 \mathrm{a}-2 \mathrm{e})$.

\subsubsection{Spectral Data for Other Analogs}

(i) $\left(2 S, 3^{\prime} S\right)-N$-(3'-amino-3'-carboxypropyl)proline (4b) $\delta_{\mathrm{H}}\left(\mathrm{D}_{2} \mathrm{O}\right) 1.87(1 \mathrm{H}, \mathrm{m}), 1.97-2.08(3 \mathrm{H}, \mathrm{m}), 2.15(1 \mathrm{H}$, $\mathrm{m}), 2.21(1 \mathrm{H}, \mathrm{m}), 2.38(1 \mathrm{H}, \mathrm{m}), 3.07(1 \mathrm{H}, \mathrm{m}), 3.25$ $(1 \mathrm{H}, \mathrm{m}), 3.44(1 \mathrm{H}, \mathrm{m}), 3.68(1 \mathrm{H}, \mathrm{m}), 3.89(1 \mathrm{H}, \mathrm{m})$, $3.99(1 \mathrm{H}, \mathrm{m})$; HRESIMS: $\mathrm{MH}^{+}$, found 217.1190. $\mathrm{C}_{9} \mathrm{H}_{17} \mathrm{~N}_{2} \mathrm{O}_{4}$ requires 217.1188 .

(ii) $\left(2 S, 3^{\prime} S\right)-N$-(3'-amino-3'-carboxypropyl)phenylalanine $(4 \mathrm{c})$

$\delta_{\mathrm{H}}\left(\mathrm{D}_{2} \mathrm{O}\right) 1.86(1 \mathrm{H}, \mathrm{m}), 1.97(1 \mathrm{H}, \mathrm{m}), 2.05(1 \mathrm{H}, \mathrm{m})$, $2.32(1 \mathrm{H}, \mathrm{m}), 2.95(1 \mathrm{H}, \mathrm{m}), 3.06(1 \mathrm{H}, \mathrm{m}), 3.95(1 \mathrm{H}$, m), $4.08(1 \mathrm{H}, \mathrm{dd}, J=5.1,8.9 \mathrm{~Hz}), 7.14-7.35(5 \mathrm{H}, \mathrm{m})$; HRESIMS: $\mathrm{MH}^{+}$, found 267.1353. $\mathrm{C}_{13} \mathrm{H}_{19} \mathrm{~N}_{2} \mathrm{O}_{4}$ requires 267.1345 .

(iii) $\left(2 S, 3^{\prime} S\right)-\mathrm{N}-\left(3^{\prime}\right.$-amino-3'-carboxypropyl)glutamic acid $(4 \mathrm{~d})$

$\delta_{\mathrm{H}}\left(\mathrm{D}_{2} \mathrm{O}\right) 1.94(1 \mathrm{H}, \mathrm{m}), 2.00-2.10(2 \mathrm{H}, \mathrm{m}), 2.13(1 \mathrm{H}$, $\mathrm{m}), 2.30-2.41(2 \mathrm{H}, \mathrm{m}), 3.05-3.14(2 \mathrm{H}, \mathrm{m}), 3.55(1 \mathrm{H}$, t, $J=6.2 \mathrm{~Hz}), 3.72(1 \mathrm{H}, \mathrm{dd}, J=5.3,7.6 \mathrm{~Hz})$; HRESIMS: $\mathrm{MH}^{+}$, found 249.1090. $\mathrm{C}_{9} \mathrm{H}_{17} \mathrm{~N}_{2} \mathrm{O}_{6}$ requires 249.1087 .

(iv) $\left(2 S, 3^{\prime} S\right)-N$-(3'-amino-3'-carboxypropyl]leucine (4e) $\delta_{\mathrm{H}}\left(\mathrm{D}_{2} \mathrm{O}\right) 0.80(3 \mathrm{H}, \mathrm{d}, J=6.6 \mathrm{~Hz}), 0.86(3 \mathrm{H}, \mathrm{d}, J=$ $6.6 \mathrm{~Hz}), 1.52-1.67(4 \mathrm{H}, \mathrm{m}), 2.16(1 \mathrm{H}, \mathrm{m}), 3.01(1 \mathrm{H}$, $\mathrm{m}), 3.12(1 \mathrm{H}, \mathrm{m}), 3.59(1 \mathrm{H}, \mathrm{m}), 3.77(1 \mathrm{H}, \mathrm{dd}, J=5.7$, $7.4 \mathrm{~Hz})$; HRESIMS: $\mathrm{MH}^{+}$, found 233.1511. $\mathrm{C}_{10} \mathrm{H}_{21} \mathrm{~N}_{2} \mathrm{O}_{4}$ requires 233.1501.

(v) (3'S, $\left.3^{\prime \prime} S\right)-N-\left\{3^{\prime}-\left(3^{\prime \prime}\right.\right.$-amino-3"-carboxypropylamino)3 '-carboxypropyl $\}$ glycine (6a)

$\delta_{\mathrm{H}}\left(\mathrm{D}_{2} \mathrm{O}\right)$ 1.95-2.06 $(4 \mathrm{H}, \mathrm{m}), 2.90-3.25(4 \mathrm{H}, \mathrm{m}), 3.71$ $(1 \mathrm{H}, \mathrm{m}), 3.89(1 \mathrm{H}, \mathrm{dd}, J=6.0,7.2 \mathrm{~Hz}), 4.07-4.16$ $(2 \mathrm{H}, \mathrm{m})$; HRESIMS: $\mathrm{MH}^{+}$, found 278.1340. $\mathrm{C}_{10} \mathrm{H}_{20} \mathrm{~N}_{3} \mathrm{O}_{6}$ requires 278.1352 .

(vi) $\left(2 S, 3^{\prime} S, 3^{\prime \prime} S\right)-N$ - $\left\{3^{\prime}-\left(3^{\prime \prime}\right.\right.$-amino-3"-

carboxypropylamino)-3'-carboxypropyl $\}$ proline (6b)

$\delta_{\mathrm{H}}\left(\mathrm{D}_{2} \mathrm{O}\right)$ 1.87-2.38 $(8 \mathrm{H}, \mathrm{m}), 2.98-3.12(2 \mathrm{H}, \mathrm{m}), 3.44$ $(1 \mathrm{H}, \mathrm{m}), 3.68(1 \mathrm{H}, \mathrm{m}), 3.71(1 \mathrm{H}, \mathrm{m}), 3.89(1 \mathrm{H}, \mathrm{dd}, J$ $=5.5,7.0 \mathrm{~Hz}), 3.99(1 \mathrm{H}, \mathrm{m})$; HRESIMS: $\mathrm{MH}^{+}$, found 318.1653. $\mathrm{C}_{13} \mathrm{H}_{24} \mathrm{~N}_{3} \mathrm{O}_{6}$ requires 318.1665.

(vii) $\left(2 S, 3^{\prime} S, 3^{\prime \prime} S\right)-N$ - $\left\{3^{\prime}\right.$-(3"-amino-3"carboxypropylamino)-3'carboxypropyl ; phenylalanine (6c) $\delta_{\mathrm{H}}\left(\mathrm{D}_{2} \mathrm{O}\right)$ 1.86-2.30 $(6 \mathrm{H}, \mathrm{m}), 2.95-3.20(4 \mathrm{H}, \mathrm{m}), 3.71$ $(1 \mathrm{H}, \mathrm{t}, J=6.2 \mathrm{~Hz}), 3.95(1 \mathrm{H}, \mathrm{m}), 4.08(1 \mathrm{H}, \mathrm{dd}, J=$ 5.1, $8.9 \mathrm{~Hz}), 7.14-7.35$ (5H, m); HRESIMS: $\mathrm{MH}^{+}$, found 368.1830. $\mathrm{C}_{17} \mathrm{H}_{26} \mathrm{~N}_{3} \mathrm{O}_{6}$ requires 368.1822.

(viii) $\left(2 S, 3^{\prime} S, 3^{\prime \prime} S\right)-N-\left\{3^{\prime}-\left(3^{\prime \prime}\right.\right.$-amino-3"carboxypropylamino)-3'-carboxypropyl $\}$ glutamic acid (6d)
$\delta_{\mathrm{H}}\left(\mathrm{D}_{2} \mathrm{O}\right)$ 1.94-2.13 (6H, m), 2.30-2.41 (2H, m), 2.95$3.14(4 \mathrm{H}, \mathrm{m}), 3.68$ (1H, t, $J=6.2 \mathrm{~Hz}), 3.80(1 \mathrm{H}, \mathrm{dd}, J$ $=5.3,7.6 \mathrm{~Hz}), 3.95(1 \mathrm{H}, \mathrm{m})$; HRESIMS: $\mathrm{MH}^{+}$, found $350.1559 . \mathrm{C}_{13} \mathrm{H}_{24} \mathrm{~N}_{3} \mathrm{O}_{8}$ requires 350.1563 .

(ix) $\left(2 S, 3^{\prime} S, 3^{\prime \prime} S\right)-N$ - $\left\{3^{\prime}\right.$-(3"-amino-3"-

carboxypropylamino)-3'-carboxypropyl $\}$ leucine (6e) $\delta_{\mathrm{H}}\left(\mathrm{D}_{2} \mathrm{O}\right) 0.80(3 \mathrm{H}, \mathrm{d}, J=6.6 \mathrm{~Hz}), 0.87(3 \mathrm{H}, \mathrm{d}, J=$ $6.6 \mathrm{~Hz}), 1.82-2.08(7 \mathrm{H}, \mathrm{m}), 3.01-3.16(4 \mathrm{H}, \mathrm{m}), 3.59$ $(1 \mathrm{H}, \mathrm{t}, J=6.0 \mathrm{~Hz}), 3.77(1 \mathrm{H}, \mathrm{dd}, J=5.5,7.5 \mathrm{~Hz})$, $3.80(1 \mathrm{H}, \mathrm{m})$; HRESIMS: $\mathrm{MH}^{+}$, found 334.1983 . $\mathrm{C}_{14} \mathrm{H}_{28} \mathrm{~N}_{3} \mathrm{O}_{6}$ requires 334.1978.

\subsection{ACE Inhibition Assay Protocol [18]}

To a test tube an appropriate amount of sample solution was added, and the solvent was evaporated in vacuo. Fourty $\mu \mathrm{L}$ of ACE $(5 \mathrm{mU})$ solution in $20 \mathrm{mM}$ phosphate buffer $(\mathrm{pH}$ 8.3) was added to the test tube, and the mixture was preincubated for $5 \mathrm{~min}$ at $37^{\circ} \mathrm{C}$. The enzymatic reaction was initiated by adding $25 \mu \mathrm{L}$ of $13.0 \mathrm{mM}$ HHL in $250 \mathrm{mM}$ sodium borate buffer $(\mathrm{pH} 8.3)$. After incubation for $1 \mathrm{~h}$ at $37^{\circ} \mathrm{C}$, the reaction was quenched by adding $12.5 \mu \mathrm{L}$ of $2 \mathrm{M}$ aqueous $\mathrm{HCl}$. After the addition of $0.2 \mathrm{M}$ phosphate buffer (pH 8.3, $875 \mu \mathrm{L}$ ), cyanuric chloride (3\%) in 1,4-dioxane (400 $\mu \mathrm{L})$ was added to the mixture with vigorous stirring. The enzyme activity in the resulting solution was evaluated by its absorbance at $382 \mathrm{~nm}$. The negative control run was identical to the above procedure without the inhibitor. Captopril was used as the positive control. A unit of inhibitory activity was defined as an amount of inhibitor needed to inhibit $50 \%$ of the $\mathrm{ACE}$ activity $\left(\mathrm{IC}_{50}\right.$ value).

\subsection{Docking Studies}

Docking calculations were performed with Gold 5.2 software. The protein data in the docking studies was obtained from Protein Databank (PDB code 1UZF). The energy minimization of ligands (nicotianamine and its analog 6c) was performed using MM2 force field with Spartan'08 software. Default parameters are used in all docking experiments and GoldScore was used as a scoring function.

\section{Results and Discussion}

Nicotianamine is a non-peptide-type amino acid trimer that includes an azetidine-2-carboxylic acid moiety as its structural feature. Determining whether the trimeric structure and the azetidine-2-carboxylic acid moiety are essential for ACEI activity would help define the mode of action of nicotianamine and aid in the development of a new type of hypertensive drug. To this end, dimeric analogs (for examining the necessity of the trimeric structure) and trimeric analogs (including other amino acid moieties instead of azetidine-2-carboxylic acid) were prepared. Five amino acids with chemically different residues were selected as follows: i) glycine without a residue, ii) L-proline with a cyclic residue, iii) L-phenylalanine with an aromatic residue, iv) L-glutamic acid with a negatively-charged residue, and v) 
L-leucine with an aliphatic bulky residue. Several practical protocols for nicotianamine synthesis are described in the literature. These are categorized based on key reactions as follows: (i) reductive amination of intermediate protected aldehydes [19-21], (ii) reduction of amide bonds via thioamide [22], and (iii) nucleophilic substitution of iodine by an amine [23]. One of our purposes was to establish the necessity of the azetidine-2-carboxylic acid moiety for ACEI activity. The moiety should be incorporated at the latter step in the synthetic scheme. In this context, the reductive amination protocol by Ofune and coworkers was the most adequate for our purposes and was adapted for our analogs' syntheses.

Aldehyde 1 [20] prepared from commercially available Lhomoserine lactone was coupled with glycine benzyl ester $2 \mathrm{a}$ via a reductive amination procedure (sodium
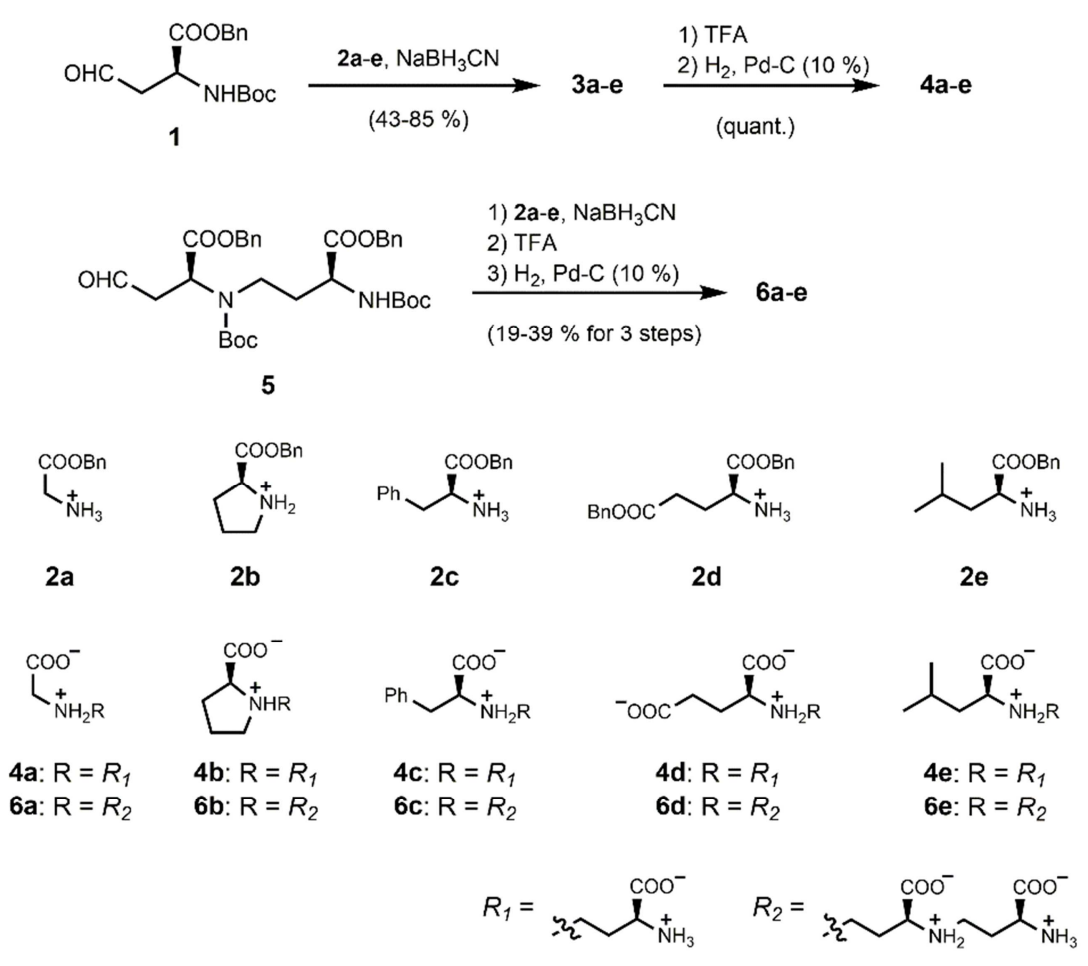

Figure 2. Syntheses of nicotianamine analogs.

The ACEI activities of ten analogs (4a-4e, 6a-6e), together with nicotianamine and captopril, were examined (Table 1). None of five dimeric analogs $4 \mathrm{a}-4 \mathrm{e}$ exhibited detectable ACEI activities $\left(\mathrm{IC}_{50}>50 \mathrm{mg} / \mathrm{L}\right)$, suggesting that the trimeric structure is essential for ACEI activity. Indeed, all trimeric analogs (6a-e) exhibited potent ACEI activities. In other words, the azetidine-2-carboxylic acid moiety is verified not to be essential for activity. The glycine analog $6 \mathrm{a}$ without a residue and the proline analog $6 \mathrm{~b}$ with a pyrrolidine as its residue exhibited three-fold higher potency $\left(\mathrm{IC}_{50}=0.15\right.$ $\mathrm{mg} / \mathrm{L})$ than that of nicotianamine $\left(\mathrm{IC}_{50}=0.50 \mathrm{mg} / \mathrm{L}\right)$. The glutamic acid analog $6 \mathrm{~d}$ (a negative-charged residue) and the leucine analog 6e (a bulky aliphatic residue) exhibited fourfold weaker activity $\left(\mathrm{IC}_{50}=2.0 \mathrm{mg} / \mathrm{L}\right)$ than that of nicotianamine, respectively. The bulky and negativelycharged residues would be inadequate for activity. cyanoborohydride, $\mathrm{MeOH}$, room temperature) to give the desired $3 \mathrm{a}$ in $67 \%$ yield (Figure 2). All protecting groups in $3 \mathrm{a}$ were then removed under mild conditions $\left\{\right.$ (i) $\mathrm{CF}_{3} \mathrm{COOH}$ (TFA), room temperature; (ii) $\mathrm{H}_{2}, \mathrm{Pd}-\mathrm{C}(10 \%)$, EtOH- $\mathrm{H}_{2} \mathrm{O}$, room temperature $\}$ to afford $4 \mathrm{a}$ quantitatively. The other analogs $4 b-4 e$ were prepared in the same manner using Lproline benzyl ester (2b), L-phenylalanine benzyl ester (2c), L-glutamic acid $\alpha, \gamma$-dibenzyl ester (2d), and L-leucine benzyl ester (2e), respectively. Aldehyde 5 was also prepared via a reductive amination of 1 with L-homoserine lactone in the same manner as described above, and the coupling reaction between 5 and 2 a was achieved under reductive amination conditions. The successive removal of all protecting groups gave the desired $6 \mathrm{a}$ in $19 \%$ yield in three steps. Analogs $6 \mathrm{~b}-$ $6 \mathrm{e}$ were also prepared in the same manner. 
Gold program [24-26]. In recent years, computational methods such as in silico docking studies provide inexpensive and efficient ways for investigating ligandprotein interactions. Docking studies can predict plausible binding features of a ligand-protein complex, and has become a powerful tool in drug discovery processes [27-29]. In current study, a crucial problem is that the features of nicotianamine's binding site (which is an allosteric site in ACE) remains unclear to date due to the lack of crystallographic data. However, it is expected that a plausible binding site could be predicted using thorough docking calculations. For example, when the ligand-protein affinity is calculated using the parameter that an arbitrary residue is set as the binding site center, a high score should only be counted if the residue is located near the true binding site. On the other hand, if the residue of interest is far away from the true binding site, its affinity score should be low. Additionally, when docking calculations are performed using the parameter that its catalytic site in ACE is occupied with a ligand such as captopril, docking calculations would indicate an allosteric binding site in the protein. Thus, docking studies make it possible to predict the presence of a previously unknown allosteric binding site.
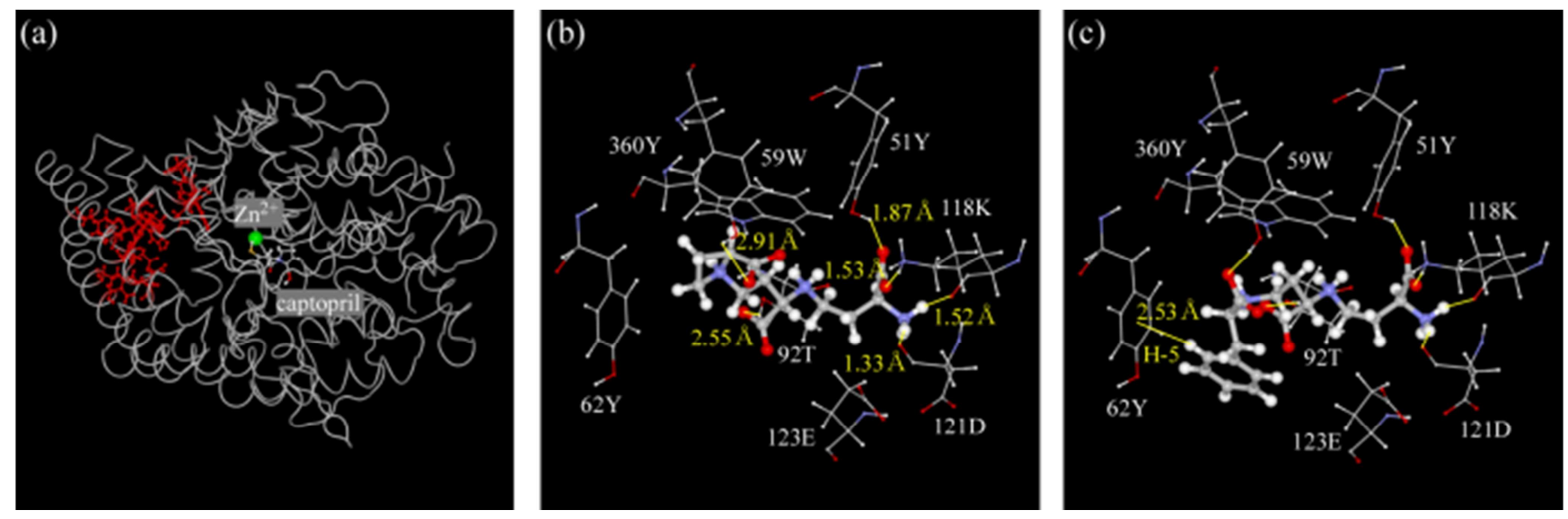

Figure 3. Nicotianamine binding site prediction with Gold program. (a) high-scored residues, as results of docking calculations, were highlighted in red (ball and stick; GoldScore > 70). In order to survey an allosteric site candidates, Gold calculations were carried out where captopril (ball and stick) occupied a catalytic site around $\mathrm{Zn}^{2+}$ ion (green sphere). (b) Zoom-in of Gold best scored docking pose for nicotianamine-ACE complex. Only residues involved in binding are shown (thin ball and stick), and observed hydrogen bonds are highlighted in yellow lines. (c) Zoom-in of Gold best scored docking pose for 6c-ACE complex. $\mathrm{CH}-\pi$ interaction, in addition to same interactions as nicotianamine, are observed (yellow line).

Docking calculations with nicotianamine were carried out and then all the GoldScores were visualized (Figure 3a). Interestingly, high-scoring residues (shown in red; GoldScore $>70$ ) were concentrated in an area away from the catalytic site, suggesting that this area is a plausible allosteric site in ACE. In top-ranked nicotianamine-ACE complex (Figure $3 \mathrm{~b}$ ), it was observed that one ionic bond (C-1 carboxyl to Lys118, $1.53 \AA$ ) and five hydrogen bonds (C-1 carbonyl to 360Tyr, $2.91 \AA ̊$; C-1' carbonyl to 92Thr, $2.55 \AA$; C-1" carbonyl to Tyr51, $1.87 \AA \AA$; C-2" ammonium to $118 \mathrm{Lys}, 1.52$ $\AA$; ; and C-2" ammonium to $121 \mathrm{ASP}, 1.33 \AA$ ) interactions. In the docking studies for analog $6 \mathrm{c}$, similar interactions with ACE were observed (Figure 3c). Additionally, an edge-toface attractive interaction was noted between the phenyl ring in analog 6c and the $p$-hydroxyphenyl ring in Tyr62 [30]. Specifically, H-5 on the aromatic ring is located at a closecontact perpendicular distance of $2.53 \AA$ above the face of the $p$-hydropheny ring in Tyr62, thus suggesting that this additional aromatic interaction is responsible for the high ACEI activity of analog $6 \mathrm{c}$.

Labeling analogs with activity is a powerful molecular tool for determining the binding profile of host-guest complex [31-32]. Analog 6c has the potential to become a valuable tool for additional biochemical study due to its easy application to photoaffinity probes using an azide and a diazirine groups [33-34]. Furthermore, analog 6c would be effective for the treatment of hypertensive disease similar to nicotianamine. Thus, these results imply that $\left(2 S, 3^{\prime} S, 3^{\prime \prime} S\right)-N$ $\left\{3^{\prime}\right.$-(3"-amino-3"-carboxypropylamino)-3'-

carboxypropyl phenylalanine $(6 \mathrm{c})$ is a potential ACE inhibitor that can contribute to both the establishment of nicotianamine's mode of action and novel methods for hypertension therapy. The application of the compound to THM and SHR is currently being studied in our laboratory.

\section{Conclusion}

A phenylalanine analog, $\left(2 S, 3^{\prime} S, 3^{\prime \prime} S\right)-N-\left\{3^{\prime}-\left(3^{\prime \prime}\right.\right.$-amino-3"carboxypropylamino)-3'-carboxypropyl $\}$ phenylalanine (6c), was developed as a nicotianamine analog, and exhibited more potent activity $\left(\mathrm{IC}_{50}=0.050 \mathrm{mg} / \mathrm{L}\right)$ than that of nicotianamine. The activity of the analog corresponds to that of captopril, which is one of the most well-known hypertensive drugs. Docking calculations using Gold program suggested the presence of a plausible allosteric binding site of nicotianamine and an edge-to-face attractive interaction between analog $6 \mathrm{c}$ and Tyr62.

\section{Acknowledgements}

We would like to thank M. Hayakari for advises of ACEI assay and the Urakami Foundation for their financial support. 


\section{References}

[1] M. A. Ondetti, B. Rubin D. W. Cushman Design of specific inhibitors of angiotensin converting enzyme; new class of orally active antihypertensive agents. Science, Vol 196, 1977, pp 441-444.

[2] A. B. AtkinsonJ. I. S. Robertson Captopril in the treatment of clinical hypertension and cardiac failure. Lancet, Vol 314, 1979, pp 836-839.

[3] E. M. Salar, S. I. Bastacky, E. K. JacksonS. P. Tofovic Captopril attenuates cardiovascular and renal disease in a rat model of heart failure with preserved ejection fraction. $J$. Cardiovasc. Pharmacol., Vol 71, 2018, pp 205-214.

[4] R. Natesh, S. L. U. Schwager, H. R. Evans, E. D. SturrockK. R. Acharya Structural details on the binding of antihypertensive drugs captopril and enalaprilat to human testicular angiotensin I-converting enzyme. Biochemistry, Vol 43, 2004, pp 8718-8724.

[5] A. A. Patchett, E. Harris, E. W. Tristram, M. J. Wyvratt, M. T. Wu, D. Taub, E. R. Peterson, T. J. Ikeler, J. ten Broeke, L. G. Payne, D. L. Ondeyka, E. D. Thorsett, W. J. Greenlee, N. S. Lohr, R. D. Hoffsommer, H. Joshua, W. V. Ruyle, J. W. Rothrock, S. D. Aster, A. L. Maycock, F. M. Robinson, R. Hirschmann, C. S. Sweet, E. H. Ulm, D. M. Gross, T. C. VassilC. A. Stone A new class of angiotensin-converting enzyme inhibitors. Nature, Vol 288, 1980, pp 280-283.

[6] M. Noma, M. NoguchiE. Tamaki A new amino acid, nicotianamine, from tabacco leaves. Tetrahedron Lett., Vol 12, 1971, pp 2017-2020.

[7] M. Takahashi, Y. Terada, I. Nakai, H. Nakanishi, E. Yoshimura, S. MoriN. K. Nishizawa Role of nicotianamine in the intracellular delivery of metals and plant reproductive development. Plant Cell, Vol 15, 2003, pp 1263-1280.

[8] R. K. Kumar, H. -H. Chu, C. Abundis, K. Vasques, D. C. Rodriguez, J. -C. Chia, R. Huang, O. K. VatamaniukE. L. Walker Iron-nicotianamine transporters are required for proper long distance iron signaling. Plant Physiol., Vol 175, 2017, pp 1254-1268.

[9] T. Nozoye, M. Otani, T. Senoura, H. NakanishiN. K. Nishizawa Overexpression of barley nicotianamine synthase 1 confers tolerance in the sweet potato to iron deficiency in calcareous soil. Plant Soil, Vol 418, 2017, pp 75-88.

[10] E. Kinoshita, J. YamakoshiM. Kikuchi Purification and identification of an angiotensin I-converting enzyme inhibitor from soy sauce. Biosci. Biotechnol. Biochem., Vol 57, 1993, pp 1107-1110.

[11] A. Hayashi, T. Nakayama, K. Murakami, Y. AoyagiK. Kimoto Effects of nicotianamine on blood pressure in Tsukuba hypertensive mice (THM). J. Jpn. Soc. Nutr. Food Sci., Vol 58, 2005, pp 315-321.

[12] S. Takahashi, T. Yoshiya, K. Yoshizawa-KumagayeT. Sugiyama Nicotianamine is a new angiotensin-converting enzyme 2 inhibitor in soybean. Biomed. Res., Vol 36, 2015, pp 219-224.

[13] K. Higuchi, S. Watanabe, M. Takahashi, S. Kawasaki, H. Nakanishi, N. K. NishizawaS. Mori Nicotianamine synthase gene expression differs in barley and rice under Fe-deficient conditions. Plant J., Vol 25, 2001, pp 159-167.
[14] D. Mizuno, K. Higuchi, T. Sakamoto, H. Nakanishi, S. MoriN. K. Nishizawa Three nicotianamine synthase genes isolated from maize are differentially regulated by iron nutritional status. Plant Physiol., Vol 132, 2003, pp 19891997.

[15] S. Kim, M. Takahashi, K. Higuchi, K. Tsunoda, H. Nakanishi, E. Yoshimura, S. MoriN. K. Nishizawa Increased nicotianamine biosynthesis confers enhanced tolerance of high levels of metals, in particular nickel, to plants. Plant Cell Physiol., Vol 46, 2005, pp 1809-1818.

[16] A. HayashiK. Kimoto Nicotianamine preferentially inhibits angiotensin I-converting enzyme. J Nutr Sci Vitaminol, Vol 53, 2007, pp 331-336.

[17] M. Hayakari, K. Satoh, H. Izumi, T. Kudoh, J. Asano, T. YamazakiS. Tsuchida Kinetic-controlled hydrolysis of LeuVal-Val-hemorphin-7 catalyzed by angiotensin-converting enzyme from rat brain. Peptides, Vol 24, 2003, pp 1075-1082

[18] M. Hayakari, R. Seito, A. Furugori, Y. HashimotoS. Murakami An improved colorimetric assay of angiotensinconverting enzyme in serum. Clin. Chem. Acta, Vol 144, 1984, pp 71-75.

[19] S. Fushiya, S. Nakatsuyama, Y. SatoS. Nozoe Synthesis of nicotianamine and a related compound, rerivatives of azetidine-2-carboxylic acid. Heterocycles, Vol 15, 1981, pp 819-822.

[20] Y. Ohfune, M. TomitaK. Nomoto Total synthesis of 2'deoxymugineic acid, the metal chelator excreted from wheat root. J. Am. Chem. Soc., Vol 103, 1981, pp 2409-2410.

[21] F. Matsuura, Y. HamadaT. Shioiri Total synthesis of 2'deoxymugineic acid and nicotianamine. Tetrahedron, Vol 50, 1994, pp 9457-9470.

[22] K. Miyakoshi, J. OshitaT. Kitahara Expeditious synthesis of nicotianamine and 2'-deoxymugineic acid. Tetrahedron, Vol 57, 2001, pp 3355-3360.

[23] M. Bouazaoui, S. Mari, P. Czernic, C. Curie, J. MartinezF. Cavelier Synthesis and biological activity of nicotianamine and analogues. Adv. Exp. Med. Biol., Vol 611, 2009, pp 555557.

[24] G. Jones, P. WillettR. C. Glen Molecular recognition of receptor sites using a genetic algorithm with a description of desolvation. J. Mol. Biol., Vol 245, 1995, pp 43-53.

[25] G. Jones, P. Willett, R. C. Glen, A. R. LeachR. Taylor Development and validation of fa genetic algorithm for flexible docking. J. Mol. Biol., Vol 267, 1997, pp 727-748.

[26] N. S. Pagadala, K. SyedJ. Tuszynski Software for molecular docking; a review. Biophys. Rev., Vol 9, 2017, pp 91-102.

[27] N. A. Roberts, J. A. Martin, D. Kinchington, A. V. Broadhurst, J. C. Craig, I. B. Duncan, S. A. Galpin, B. K. Handa, J. KayA. Kröhn Rational design of peptide-based HIV proteinase inhibitors. Science, Vol 248, 1990, pp 358-361.

[28] O. M. Becker, D. S. Dhanoa, Y. Marantz, D. Chen, S. Shacham, S. Cheruku, A. Heifetz, P. Mohanty, M. Fichman, A. Sharadendu, R. Nudelman, M. KauffmanS. Noiman An integrated in silico 3D model-driven discovery of a novel, potent, and selective amidosulfonamide 5-HT1A agonist (PRX-00023) for the treatment of anxiety and depression. $J$. Med. Chem., Vol 49, 2006, pp 3116-3135. 
[29] K. K. Reddy, S. K. Singh, S. K. TripathiC. Selvaraj Identification of potential HIV-1 integrase strand transfer inhibitors; in silico virtual screening and QM/MM docking studies. . SAR QSAR Environ. Res., Vol 24, 2013, pp 581-595.

[30] C. A. Hunter MELDORA LECTURE. The role fo aromatic interactions in molecular recognition. Chem. Soc. Rev., Vol 23, 1994, pp 101-109.

[31] T. Böttcher, M. Pitscheider S. A. Sieber Natural products and their biological targets; proteomic and metabolomic labeling strategies. Angew. Chem. Int. Ed., Vol 49, 2010, pp 2680-2698.
[32] S. Sato, A. Murata, T. Shirakawa M. Uesugi Biochemical target isolation for novices; affinity-based strategies. Chem. Biol., Vol 17, 2010, pp 616-623.

[33] F. Kotzyba-Hibert, I. KapferM. Goeldner Recent trends in photoaffinitylabeling. Angew. Chem. Int. Ed. Engl., Vol 34, 1995, pp 1296-1312.

[34] M. Hashimoto Y. Hatanaka Recent progress in dazirine-based photoaffinity labeling. Eur. J. Org. Chem., Vol 2008, 2008, pp 2513-2523. 